\title{
IMPROVING STUDENTS' ACHIEVEMENT IN WRITING DESCRIPTIVE TEXT THROUGH THINK PAIR SHARE
}

\author{
*Adly Syahputra \\ **Elia Masa Ginting
}

\begin{abstract}
Students' achievement in writing descriptive text is very low, in this study Think Pair Share (TPS) was applied to solve the problem. Action research in conducted for the result and the technique to collect the data, qualitative and quantitative are applied in this research. The subject of this research is grade VIII in Junior High School (SMP Bilang Huluh) Rantau Parapat. In the first evaluation $(66,4375)$ increased to the mean of second evaluation $(78,125)$ and the mean of third evaluation $(87,5625)$. Observation result showed that the students gave their good attitudes and responses during teaching and learning process by applying the application of TPS (Think Pair Share) method. Questionnaire and interview report showed that students agree that the application of TPS (Think Pair Share) method had helped them in writing descriptive text. It can be conclude that the students' achievement is improved when thay are tought through TPS Method.
\end{abstract}

Key Words: Achievement, Writing, Descriptive Text and Think Pair Share

\footnotetext{
* A graduate of English Language and Literature Department of UNIMED

** A lecturer of English Language and Literature Department of UNIMED
} 


\section{INTRODUCTION}

\section{The Background of The Study}

English was the language of global terms that need to be developed in Indonesia. Due to the ability to speak English, people was able to obtain and provide information that was very important to develop oneself and the environment. Therefore, in Indonesia Language has been incorporated into the curriculum of English schools and colleges so that English can be taught to the Indonesian people well and in line with expectations stated in the opening of the 1945 constitution that was to increase the nation intellectual life.

In learning the English language, there are four skills should be taught to students. They are speaking, listening, reading and writing. In practice, learning the lessons taught writing after speaking, listening and reading. But this does not state that learning writing was not important. In fact, since writing was a very important lesson learning why writing was taught after the third important element was taught and writing also was the very difficult subject for the students. It was related to Oshima and Hogue (1999:3) that writing, particularly academic writing was not easy. It takes study and practice to develop this skill. For both native speaker and new learners of English, it was important to note that writing was a process, not a "product". This means that a piece of writing, whether it was a composition for your English class or a lab report for your chemistry class was never complete; that was, it was always possible to review and revise, and review and revise again.

Writing was a very important capability for being owned by students, writing was also an excellent communication tool. Through writing, each person was able to convey feelings, ideas, and announcements to others. Sharples (1999:8) actually, writing was an opportunity; it allows students to express something about themselves, explore and explain ideas. Student can convey their ideas in their mind by organizing them into a good text so that the others know them and they can think critically. Therefore, learning was very important for improved writing in particular learning of English in Indonesia because the writing was a process of transformation of thoughts and ideas into tangible forms of writing. In addition, many people choose writing as a means of effective and efficient communication of information to be conveyed in some 
ways like posting letters, business letters and important information in a company's product.

In the Kurikulum Tingkat Satuan Pendidikan (KTSP) 2006 syllabus of junior and senior high schools curriculum require students to be able to write some kind of genre in writing. They are narrative, recount, descriptive, report, explanation, analytical exposition, hortatory exposition, procedure, discussion, reviews, anecdote, spoof, and news items.

Based on the above, the descriptive text was one genre that must be mastered by students in learning English. And theoretically, according to Ervina Evawina S (2010:7) descriptive paragraph was a paragraph vividly portrays a person, place, or thing in such a way that the reader can visualize the topic and enter into the writer's experience.

In fact, not all students are able to write descriptive paragraph properly and in accordance with the existing elements in the descriptive text. Based on the researcher's observation at the time of the teaching practice program (PPL) contained $75 \%$ of students who were unable to write a descriptive paragraph. Teachers of English already taught the material to students well but the students still had the problem in writing descriptive paragraph. In addition, the researcher also had looked the teachers of English language teaching by lecture, and then asked the students to write descriptive paragraph individually.

From the above, student's ability to write descriptive paragraph was very less because the learning methods that was adopted by teachers of English language was a method that does not fit anymore in this day because it reduced the interest and liveliness of the students in the learning process so that students were bored and did not want to continue learning as they should.

At this present time, there are already implementations Learning Revolution in teaching and learning that was learning was no longer centered on teachers. In other words, it was called "Teacher Centered Learning (TCL)" but it has been centered on students. It was called "Student Centered Learning (SCL)" theoretically SCL was an approach to education focusing on the needs of the students, rather than those of others involved in the educational process, such as teacher and administrators (http://en.wikipedia.org). So the teacher was only as facilitators and a provider of 
solutions in learning was no longer only as a source of knowledge in the learning process.

Based on the above, the researcher offered a method that had to be applied in the learning process of writing descriptive paragraph because Ransdell and Laure Barbier (2002: 143) maintain that a good writing strategy can be trained, and it can improve writing performance. The method that was offered by researcher was the implementation of Student Centered Learning (SCL) and the development of Cooperative Learning (CL) that according to Slavin (1995:2) Cooperative Learning refers to variety of teaching methods in which students work in small group to help one another learn academic content. In cooperative classrooms, students are expected to help each other to discuss and argue with each other, to assess each other's current knowledge and fill in gaps in each other's understanding, so that the interest and active students in the learning process could be improved not only individually but in groups or together. Learning method which the researcher refers to was Think Pair Share (TPS).

Think Pair Share (TPS) was one of the Cooperative Learning methods which poses a challenging or open-ended question and gives students a half to one minute to think about the question. Students then pair with a collaborative group member or neighbor sitting nearby and discuss their ideas about the question for several minutes. The think-pair-share structure gives all students the opportunity to discuss their ideas (www.wcer.wwasc.edu). It was designed to motivate the students to tackle and succeed at problem which initially were beyond their ability. It was based on the simple nation of mediated learning. Obviously, one alternative to solve the problem of writing descriptive paragraph was by applying TPS.

With the application of this method was expected to enhance students' skills in writing descriptive paragraph properly and in accordance with the existing elements in the descriptive paragraph.

\section{The Problem of The Study}

Based on the background of the study, the problem of this study was formulated as follows:

"How do apply Think Pair Share method to improve the students' achievement in writing descriptive Text?" 


\section{The Scope of The Study}

There are many genres of writing learnt in the SMP (Junior High School) such as recount, narrative, procedure, descriptive, and etcetera. Specipically this study focused on improving on the students' achievement in writing descriptive text. The method that was used to improve students' achievement on writing descriptive paragraph was Think Pair Share (TPS) method. In other words, the study was concentrated on the genre of descriptive.

\section{The Objective of The Study}

In relation to the problem, the objective of the study was to investigate and to find out the improvement of students achievement in writing descriptive text through the application of Think Pair Share (TPS) method.

\section{The Significant of The Study}

Finding of this study was expected to be relevant and useful in that finding are expected

1) to motivate the students to be better on writing descriptive paragraph,

2) to provide significant information for the English teacher in their attempt to decide the TPS in teaching descriptive writing in senior high school,

3) to increase the readers knowledge about TPS and descriptive paragraph and,

4) to help the next researcher candidate of the teacher to apply a model in teaching learning process.

\section{THEORETICAL FRAMEWORK}

\section{Achievement}

Travers (1970:447) states that achievement was the result of what an individual has learned from some education experience. Additionally, Yelon, Weinstein, and Weener (1977:301) express achievement as the successfulness of individual, while another source Smith and Hudgins (1964:95) says that achievement was to do one's best, to be successful to accomplish tasks requiring skill and effort and to be recognized by authority. 
Based on the opinions above, it can be concluded that achievement was the result, the successfulness, the extent or ability, the progress in learning education experiences that the individual indicates relation with his/her educational learning. Achievement concerns with what someone has actually learnt whereas aptitude was the potential for learning something. In other words, achievement was a success in reaching particular goal/status or standard, especially by effort, skill, courage, and so on.

\section{Writing}

Writing was a process of formulating and organizing ideas in right words to deliver the aim and present them on a piece of paper. According to Jones in R. Cooper and Odell (1977:33) writing was synonymous with discourse, and discourse was discussed in terms of its aims, it relate to the function of language, and in terms of its feature, which are the separate elements, devices, and mechanism of language.

On the other hand, Reinking, Hard and Osten (1993:188) state that writing was a way of communication and of course communicates all the time. And then Deporter and Heracki (2002:179) explain that writing was a whole brain activity, which use bright brain side (emotion) and left brain side (logic). Although right and left brain sides are used in writing, right brain side has a big position because it was a place which appears new ideas and emotion.

From the explanation above, we can state that writing was a whole brain activity to formulate and organize ideas in right words to deliver and communicate the aims to the reader and present it on a piece of paper.

\section{Descriptive Text}

A descriptive text was a piece of writing that was intended to convey meaning to the reader through sensory details and provides image to the reader (http://www.ehow.com). Additionally, descriptive text was a paragraph may be defined as a group of sentences that are closely related in thought and which serve one comment purpose often used to describe what a person looks like and acts like, what a place looks like, and what an object looks like (http://www.examples-help.org.uk). Furthermore, Pardiyono (2007:34) state that description paragraph was a type of written text paragraph, in which has the specific function to describe about an object (living or nonliving things) and it has the aim that was giving description of the object to the reader clearly. 
From the definition above, it can be concluded that description paragraph was a paragraph that describes a particular person, place or event in great deal. Description writing vividly portrays a person, place, or things in such a way that the reader can visualize the topic and enter into the writer's experience. It was a way to enrich others forms of writing or as a dominant strategy for developing a picture of what something looks like.

Furthermore, Jolly (1984:470) assert there are five types of descriptive writing paragraph. They are:

a. Describing Process

Describing a process not only explains how something was done, but also explains why it was done and what was needed to complete the process.

b. Describing and event

To describe an event, a writer should be able to memorize and remember what happened in the event. Supposed the writer will write about Tsunami that was happened in Japan. In this case, he / she has to explain all details related to the event, so that the readers can imagine the real situation and condition.

c. Describing a personality

In describing a person, the first thing that we do was recognizing his/her individual characteristics. We need to describe people occurs fairly areas of physical attribute (hair, eyes), emotional (warm, nervous), moral attributes (greedy, honest, worthy, trust), and intellectual (cleverness, perception)

d. Describing a place

Presenting something concrete was the way to describe place, for example: a home, a hospital, and school.

e. Describing an object

To describe an object accurately was done by providing the physical characteristics of the object such as the color, form, shape, and so on.

\section{Part of Descriptive Text}

There are three part of descriptive text. They are: 1 . Social function, which was to describe a particular person, places, or things. 2. Generic Structure, which was divided in to two. They are: a) identification: identifies the phenomenon to be described, and b) description: describe parts, qualities, characteristics. 3. Significant lexico- 
grammatical feature, that was focus on specific participant, use simple present tense. (http://teacherside.blogspot.com). Other source, Pardiyono (2007:34) maintain that three parts of descriptive, they are (1) communicative purpose, that was to describe an object (human and non-human). (2) rhetorical structure, there are two parts of rhetorical structure a) identification, that was statement that consist of one topic to describe; $b$ ) description, that was consist of the detail description about object that identify in identification, and (3) grammatical patterns, it was needed to understand that in descriptive paragraph, declarative sentence was used and using present forms.

From the two explanations above, we can conclude that the part of descriptive paragraph was divided in to three parts, they are:

a. Social Function

Describe the characteristics and conditions of the object either person, thing, place, or animal) by using adjective and attribute.

b. Generic structure

It was divided into two part they are a) identification was to identify the phenomenon that was described, and b) description was to describe the qualities, characteristics, condition, and part of an object in detail.

c. Grammatical feature

In description paragraph, it uses present tense as normally.

\section{Think Pair Share (TPS)}

The think, pair, share strategy was a cooperative learning technique that encourages individual participation and was applicable across all grade levels and class sizes. Students think through questions using three distinct steps:

1. Think: Students think independently about the question that has been posed, forming ideas of their own.

2. Pair: Students are grouped in pairs to discuss their thoughts. This step allows students to articulate their ideas and to consider those of others.

3. Share: Student pairs share their ideas with a larger group, such as the whole class. Often, students are more comfortable presenting ideas to a group with the support of a partner. In addition, students' ideas have become more refined through this three-step process.

(www.teachervwasion.fen.com) 
On the other hand, Think-Pair-Share was a strategy designed to provide students with "food for thought" on a given topics enabling them to formulate individual ideas and share these ideas with another student. It was a learning strategy developed by Lyman and associates to encourage student classroom participation. Rather than using a basic recitation method in which a teacher poses a question and one student offers a response, Think-Pair-Share encourages a high degree of pupil response and can help keep students on task.

\section{The steps of Think Pair Share}

1) With students seated in teams of 4 , have them number them from 1 to 4 .

2) Announce a discussion topic or problem to solve. (Example: Which room in our school was larger, the cafeteria or the gymnasium? How could we find out the answer?)

3) Give students at least 10 seconds of think time to THINK of their own answer. (Research shows that the quality of student responses goes up significantly when you allow "think time.")

4) Using student numbers, announce discussion partners. (Example: For this discussion, Student \#1 and \#2 was partners. At the same time, Student \#3 and \#4 will talk over their ideas.)

5) Ask students to PAIR with their partner to discuss the topic or solution.

6) Finally, randomly call on a few students to SHARE their ideas with the class.

Teachers may also ask students to write or diagram their responses while doing the Think-Pair-Share activity. Think, Pair, Share helps students develop conceptual understanding of a topic, develop the ability to filter information and draw conclusions, and develop the ability to consider other points of view.

(http://olc.spsd.sk.ca)

\section{METHODOLOGY}

This research was conducted as an action research procedure since involved a substantive act with a research procedure to find the improvement. Stringer (2007:1) maintains that action research was systematic approach to investigation that enables people to find effective solutions to problems they confront in their everyday life. Action research focused on specific situations and localized solutions. Action research provided the means by which people in schools, business and community 
organizations; teachers; and health and human services may increase the effectiveness of the work in which they are engaged

In this research, the data was collected by quantitative and qualitative approach. Quantitative data was collected by administrating composition text and qualitative was one research method that was describing the situation and the event (Sugyono, 2004:4).

Quantitative data was collected through evaluation sheet which administrated by the researcher. For gathering the qualitative data, the researcher used observation sheet, interview sheet and questionnaire. Observation sheet was used to identify all the condition that happened during the teaching learning process including teacher, students and the context of situation that were done by the collaborator, interview sheet was used when the writer want to identify the problems occurred in the learning process and questionnaire as the personal records which usually taken by the writer that was written up daily.

A collaborator was asked to observe and evaluate all the situations during the teaching learning process, the researcher, the students and the class in the teaching learning process.

\section{RESULT AND DISCUSSION}

The students' score increased from first evaluation to third evaluation. The writer gave the evaluation in second, fourth, and six meeting. During the research, it was found out that the students' score kept improving from first evaluation to last evaluation. By application TPS the students' score was significantly improved. The ranges of score improvement can be seen in the following table:

\section{Range of Score Improvement}

\begin{tabular}{|c|c|c|}
\hline $\begin{array}{c}\text { Range of Score } \\
\text { Improvement }\end{array}$ & Students' Initial & Total \\
\hline $26-36$ & & 7 \\
\hline $21-25$ & & 8 \\
\hline $16-20$ & & 9 \\
\hline $11-15$ & & 5 \\
\hline $6-10$ & & 3 \\
\hline \multicolumn{2}{|c|}{ Number of Students } & 32 \\
\hline
\end{tabular}

a. Students who got the improvement score about 26-30:

from 60-90 


\section{* from 60-90 \\ * from 60-90 \\ * from 60-90 \\ * from 65-94 \\ * from 60-88 \\ * from 62-89}

There were 7 students who got the improvement of score $26-30$. They were students who did not like English. But, after the teacher paid attention to them more, asked them problem, and applied TPS Method, they became interested in writing descriptive text.

b. Students who got the improvement score about 21-25

$$
\begin{array}{ll}
* & \text { from 65-90 } \\
* & \text { from 65-90 } \\
* & \text { from 63-88 } \\
* & \text { from 65-90 } \\
* & \text { from 70-93 } \\
* \quad \text { from 67-90 } \\
* \quad \text { from 65-87 } \\
* \quad \text { from 65-86 }
\end{array}
$$

There were 8 students who got the improvement of score $21-25$. They were active students during teaching learning process. Almost of them got points 87 up in the last evaluation. They were active from the first until the last meeting in asking questions and they discussed every problem that they faced with their own team and pair so that their scores also kept improving.

\section{c. Students who got the improvement score about 16-20}

$$
\begin{array}{ll}
* & \text { from 64-84 } \\
* & \text { from 70-90 } \\
* & \text { from 69-89 } \\
* & \text { from 63-83 } \\
* \quad \text { from 68-87 } \\
* \quad \text { from 70-88 } \\
* \quad \text { from 73-90 } \\
* \quad \text { from 70-86 }
\end{array}
$$




\section{* from 74-90}

There were 9 students who got the improvement of score $16-20$. Even though the improvement was not so high, it did not mean the students in this range were not competent in writing descriptive text. Two of them achieved satwasfying score up to 90 that are $\mathrm{PH}$ and SF in the last evaluation. Then the low score in this range was just 83, it meant they could pass the test well.

\section{d. Students who got the improvement score about 11-15}

\section{* from 75-90 \\ * from 70-85 \\ * from 70-85 \\ * from 65-80 \\ - from 60-75}

There were 5 students who got the improvement of the score 11-15. The score improvement was not too high almost students in this range were smart students. There was one student who got the score just 75 in the last evaluation. It was RTI, but RTI still passed the evaluation. Because they were very smart students, sometimes they did not pay attention to the teacher and in their own team, they were not serious to hear the explanation. But, they kept improve their score until the last writing evaluation because of the TPS method.

\section{e. Students who got the improvement score about 6-10}

\section{* from 80-90 \\ * from 76-85 \\ * from 73-80}

There were 3 students who got the improvement of score 6-10. The score improvement was low, but in these range just three students who got the improvement from 6 until 10. Then no one got lower than 80. It meant they are good students but they did not pay attention to the lesson that was given by the teacher.

There were difference in the lowest and the highest of students' writing score in each writing evaluation which was given during the research. The differences showed that there was a significant improvement of students' writing. The improvement of students' score in each writing evaluation can be seen in the following table:

\section{Comparison Score of Students' Writing Evaluation}




\begin{tabular}{|c|c|c|c|}
\hline \multirow{2}{*}{ Type of Score } & Evaluation I & Evaluation II & Evaluation III \\
\cline { 2 - 4 } & M1 & M4 & M6 \\
\cline { 2 - 4 } & \multicolumn{2}{|c|}{ Cycle I } & Cycle II \\
\hline Lowest Score & 60 & 70 & 75 \\
\hline Highest Score & 80 & 85 & 90 \\
\hline N & 32 & 32 & 32 \\
\hline
\end{tabular}

Note:

\section{M $\quad$ Meeting \\ $\mathrm{N} \quad=$ Number of Students}

From the table above, it was seen that students' score kept improving. In writing evaluation I, the lowest score was 60 and the highest score was 80. In writing Evaluation II, the lowest score was 70 and the highest score was 85 whereas in the last writing evaluation, the lowest score was 75 and the highest score was 90 . It showed the significant improvement in students' writing descriptive text.

The improvement of students' score in writing descriptive text through TPS (Think Pair Share) also can be seen from the mean of the students' score in every writing evaluation. The mean of students' score can be seen below:

$$
\begin{aligned}
& \tilde{X} \quad=? \begin{array}{lll}
2126 & 100 \% \quad=66,4375
\end{array} \\
& 32 \\
& \tilde{X} \quad=\frac{2500}{} 100 \% \quad=78,125 \\
& 32 \\
& \tilde{X}=\frac{2802}{2} 100 \%=87,5625 \\
& 32
\end{aligned}
$$

The Improvement of Mean Scores of Students' Writing

\begin{tabular}{|c|c|c|l|}
\hline \multicolumn{2}{|c|}{ Meeting } & Total Score & Mean \\
\hline Evaluation I (Cycle I) & I & $\mathbf{2 1 2 6}$ & $\mathbf{6 6 , 4 3 7 5}$ \\
\hline Evaluation II (Cycle I) & II & $\mathbf{2 5 0 0}$ & $\mathbf{7 8 , 1 2 5}$ \\
\hline Evaluation III (Cycle II) & III & $\mathbf{2 8 0 2}$ & $\mathbf{8 7 , 5 6 2 5}$ \\
\hline
\end{tabular}

The mean of the students' score in the first meeting was the lowest of all meetings. In the last meeting, the students' score improved. From the data analysis, the 
mean score of the students' writing increased from 66,4375 to 87,5635 . It meant that the ability of students in writing descriptive text was improved.

In this research, the indicator of successful in writing descriptive text was if 75 $\%$ of students have got score up to 75 in their writing evaluation because the English passing grade at the school was 75 . The number of the students who were competent in writing descriptive text was calculated below:

$$
\begin{aligned}
& P 1=\frac{2}{32} \times 100 \%=6,25 \% \\
& P 1=\frac{26}{32} \times 100 \%=81,25 \% \\
& P 1=\frac{32}{P} \times 100 \%=100 \%
\end{aligned}
$$

32

Table 4.8 the Percentage of Students' Writing Descriptive Text

\begin{tabular}{|c|c|c|c|c|}
\hline Evaluation & Cycle & Meeting & Students who got score 75 up & Percentage \\
\hline I & I & I & $\mathbf{2}$ & $\mathbf{6 , 2 5 \%}$ \\
\hline II & I & IV & 26 & $\mathbf{8 1 , 2 5 \%}$ \\
\hline III & II & VI & 32 & $100 \%$ \\
\hline
\end{tabular}

In writing evaluation I, there were 2 students who got point 75 up. The percentage of students' achievement in descriptive text kept increasing when TPS method was applied. In the first cycle, $6,25 \%$ students got points 75 up whereas in the second cycle $100 \%$ students who got points 75 up. The range of the first meeting (6, $25 \%$ ) and the last meeting (100\%) was $93,75 \%$. It had been proved that $93,75 \%$ students got the good score on their writing achievement. It can be concluded that TPS method worked effectively and efficiently in helping students in improving their achievement in writing descriptive text.

\section{Qualitative Data}

The qualitative data were taken from observation sheet, questionnaire sheet and interview that gained within two cycles. 


\section{Observation Sheet}

From the result of observation sheet, it can be concluded that teaching learning process by applying TPS method run well. The situation of teaching learning process was comfort, lively, and enjoyable. Because from the data that was taken from the first (I) meeting to the last (VI) meeting we can find out that the Note in the data got good and very good. It means the score in this data was just gotten from 3 to 4.

So this TPS method created a good environment in teaching learning writing in which students became active in the process of writing, focus their mind to the teachers' explanation, and share in their team and pair and then finish in individually. In individually work, the students could improve their confidence to finish the work because they had discussed in team and pair.

\section{Interview}

From the interview data those were taken by the teacher and the students from the first meeting and the last meeting, we could find out that the teacher was very interesting to the students because the students were very active and enjoyed with English but students ability in writing descriptive text was not good enough and then the teacher did not have effort to improve it.

From the interview with the students in the first meeting, it can be found out that the students very interesting with English and most of the students like to write descriptive text, because from 6 students that the writer interviewed said like. So from this data we can conclude that most of the students like to write the descriptive text. That was why it was needed to improve their achievement in writing descriptive text by the application of TPS.

From the second interview that was taken from teacher, it can be find out that the application of TPS in teaching learning process especially in writing descriptive text was very helpful to improve the ability of students in writing descriptive text. And according to the teacher this method was very good because can make the students became active and enjoy the lesson.

Furthermore, from the last interview that was taken from the students it can be find out that most of the students like this method and the said that this method was very good to improve their achievement in writing descriptive text because they could be 
active and enjoy the material. And from the 6 students, all of them said TPS was very good and just one student said that it was very busy but the student also like.

So, from the entire interview, it can be concluded that TPS method was very good to improve the students' achievement in writing descriptive text at SMP N 1 Bilah Huluh grade IX and the teacher will apply TPS in teaching learning process not only writing but also another subject.

\section{Questionnaire}

From the result of questionnaire, it can be found out that TPS method can improve the achievement of students because from the data no one of the students fill in disagree and strongly disagree then no more than 4 students fill in the neutral. So most of the students fill in agree and strongly agree. It meant that this TPS method was very good for the students.

In significantly, from the data that was taken from questionnaire sheet I we could account that from the statement 1 until statement 8 , the percentage of strongly agree was 331 with mean 41, 40625\%, agree 431, $25 \%$ with mean 53, $90625 \%$, neutral $37,5 \%$ with mean $4,6875 \%$ and disagree and strongly disagree $0 \%$. So, from this questionnaire data we can concluded that the students was very interesting and enjoy the TPS method in teaching learning process especially in writing descriptive text.

Besides that, from the data that was taken from the questionnaire sheet 2 it can be found in the first statement that the percentage of students who chosen a was 71,875 $\%$, b was 3, $125 \%$, c was $25 \%$ and d was $9,375 \%$. It meant that most of students had learned to work to gather from this TPS method. So they were active in teaching learning process. And then from the statement 2 the students who chosen a was 43, 75 $\%$, b was $28,125 \%$, c was $15,625 \%$ and $\mathrm{d}$ was $12,5 \%$. It meant that most of students had learned about pair accountability and pair responsibility. In additional, from the statement 3 the students who chosen a was $84,375 \%$, b was $6,25 \%$, c was $6,25 \%$ and $\mathrm{d}$ was $3,125 \%$. It meant that most of students in this research had learned to produce something alone.

From the all questionnaire data, it can be concluded that the students were very interesting and enjoying the TPS method and they the students were not only improve 
their achievement in writing descriptive text but also improve their teamwork, responsibility and self confidence.

\section{CONCLUSION AND SUGGESTION}

\section{Conclusion}

Having analyzed the data that have been presented in the previous chapter, it was found that average scores of students in every evaluation kept improving. It can be said that there was a significant improvement on the students' achievement in writing descriptive text by applying the application of Think Pair Share method. It can be seen from the improvement of mean of students' score, namely: the mean of first evaluation $(66,4375)$ increased to the mean of second evaluation $(78,125)$ and the mean of third evaluation $(87,5625)$. The score continuously improved from the first evaluation to the third evaluation. Observation result showed that the students gave their good attitudes and responses during teaching and learning process by applying the application of TPS (Think Pair Share) method. Questionnaire and interview report showed that students agree that the application of TPS (Think Pair Share) method had helped them in writing descriptive text. it can be concluded that the application of TPS method significantly improved students' achievement in writing descriptive text.

\section{Suggestion}

The result of this study showed that the application of TPS method could improve students' achievement in writing descriptive text. In relation to the conclusion above, some points are suggested, as follow:

1. the English teacher are suggested to use TPS (Think Pair Share) method as teaching method to stimulate the students' learning writing spirit in teaching writing process.

2. For the readers who are interested for further study (university students) related to this research should explore the knowledge to enlarge the understanding about how to improve students' achievement in writing and search another reference.

\section{REFERENCES}

Deporter, B. and Heracky. M. 2002. Quantum Learning. Bandung: Penerbit Kaifa Evawina S., Ervina. 2010. Thesis of Improving Students' Achievement on Writing 
Descriptive Paragraph through the Application of Student Team Achievement Divwasion. Medan: State University of Medan.

Pardiyono. 2007. Pasti Bisa! Teaching Genre Based Writing. Yogyakarta: CV. Andi Offset.

Mulyasa, E. 2006. Kurikulum Tingkat Satuan Pendidikan. Bandung: Remaja Rosdakarya Offset Bandung.

Oshima, A. And Hogue. 1999. Writing Academic English; Third Edition. United State of America: Addwason Wesley Publwashing Company.

Ransdell, Sarah. And Marie-Laure B. 2002. New Direction for Research in L2 Writing; Studies in Writing. Dordrecht: Kluwer Academic Publwasher.

Reinking, Hart A. And Osten, R. 1993. Strategies for Successful Writing; rhetoric, Reader and Handbook. New Jersey: Prentice Hall

Sharples, M. 1999. How We Write; Writing as Creative Design. London: Routledge.

Slavin, E. Robert. 1995. Cooperative Learning Theory; Research and Practice. New York: The Hopkins University.

Stringer, Ernest T. 2007. Action Research Third Edition. United State of America: Sage Publication Inc.

Travers, John P. 1970. Fundamental of Educational Psychology. Scranton, Pensylvania: International Textbook Company.

About Descriptive Paragraph in (http://www.ehow.com). Accessed on October, $15^{\text {th }} 2011$

Student Centered Learning in (http://en.wikipedia.org). Accessed on October, $6^{\text {th }}$ 2011 
(http://olc.spsd.sk.ca). Accessed on November, 13 ${ }^{\text {th }} 2011$

(www.teachervwasion.fen.com). Accessed on November, 17 2011 